\title{
「M\&P2010 機械材料・材料加工部門技術講演会」 小特集号発刊にあたっで
}

\author{
Special Issue on M\&P2010, The 18th Materials and Processing Conference \\ Tsutomu MURAI ${ }^{* 1}$ \\ ${ }^{* 1}$ Department of Industry-Academic Collaboration, Japan Science and Technology Agency \\ Science Plaza, 5-3 Yonban-cho, Chiyoda-ku, Tokyo 102-8666, Japan
}

村井 勉 ${ }^{* 1}$

第 18 回機械材料・材料加工部門講演会が 2010 年 11 月 27，28 日に東京大学本郷キャンパスで開催されました. 今回の 講演会のメインテーマは,「ものづくりにおける基礎研究と先端技術の融合」であり, 特別講演会 1 件, 技術フォーラムが 1 件, 国際ワークショップが 1 件開催され，技術講演会では 19 のオーガナイズドセッションに合計 234 件の講演があり, 参加人数も 350 人を超え, 大変盛況な講演会となりました. 改めて,関係各位の御努力と参加いただいた皆様に感謝致しま す.

特別講演会は, 東京大学の中須賀真一教授から,「超小型衛星による新しい宇宙開発への挑戦」と題して, 低コストでコ ンパクトに各機能をパッキングした小型衛星の開発の歴史と現状について興味深いご講演を頂きました. 技術フォーラムは, 日本航空宇宙学会材料部門との共催で「航空宇宙システムの高度化に向けた最近の材料技術」と題して 6 件の講演が行わ れました．国際ワークショップは，「International Workshop on Smart Materials and Related Technologies 2010」と題して，2 日間 に亘って 13 件の講演等が行われ，活発な議論が交わされました.

各オーガナイズドセッションと講演件数は，以下の通りでした. セラミックス・セラミックス基複合材料 (12 件), コー ティング・溶射・薄莫プロセス（8 件），溶融加工・半凝固加工（7 件），金属・金属基複合材料（15 件），塑性加工とその 周辺技術 (11 件)，アルミニウム合金およびマグネシウム合金の創製と加工 (11 件)，材料・加工・構造物の信頼性を支え る評価・モニタリング技術 (23 件), 締結・接合部の力学・プロセスと信頼性評価 (16件), 高分子・高分子基複合材料 (27 件), 摩擦・摩耗材料 (13 件), 材料加工における最近の話題 (10 件), 粉末成形とその評価 (8 件), 生体・環境適合型材 料の創製と特性評価（14 件），知的材料・構造システムおよび複合機能・デバイス (19 件)，溶接・接合のプロセスと評価 (14 件), 固相微粒子による成膜技術とその応用 (6 件), 高エネルギ一加工 (5 件), 材料・構造部材の動的特性（15 件). 本特集号では，講演頂いた中から，小特集号への推薦調査の結果に基づいて講演を精選し，校閲・編集作業を経てノー 卜を掲載致しました. 本特集号の発行に関しましては，ご執筆頂いた著者をはじめ関係者方々に感謝致します，当部門は， 材料と加工の接点に注目し「ものづくり」に直結した研究，開発を重視しています. 迅速に産業界の役に立てる情報を提供 するという意味で, 速報性を大事にし, 厳しい日程で著者の方々には執筆していただき, 編修委員にも大変なご負担を頂き ました. 本特集号が，機械材料・材料加工分野に関心のお持ちの産学官の研究者，技術者の皆様に少しでもお役に立てれば 幸甚です。

$\lceil M \& P$ 機械材料・材料加工部門技術講演会」企画小委員会

主查 藤本浩司 (東京大学) 幹事 岡部洋二 (東京大学) 委員 秦 誠一 (東京工業大学), 武藤睦治 (長岡技術科学大学) 三浦秀士 (九州大学), 浅沼 博 (千葉大学), 香川裕之 (関西電力 (株))

\footnotetext{
*原稿受付 2011 年 6 月 20 日

*1 正員, フェロー, (独) 科学技術振興機構 （干102-8666 東京都千代田区四番町 5-3)

E-mail: t3murai@jst.go.jp
} 